\title{
Effects of age, sex, and environmental factors using samples of hair from residents living in the vicinity of the Cho Dien lead/zinc mine (Vietnam)
}

\author{
N. T. T. Hien ${ }^{1}$, M. Yoneda ${ }^{1}$, Y. Matsui ${ }^{1}$, S. Fujii ${ }^{2} \&$ H. T. Hai ${ }^{3}$ \\ ${ }^{1}$ Graduate School of Engineering, Kyoto University, Japan \\ ${ }^{2}$ Graduate School of Global Environmental Studies, \\ Kyoto University, Japan \\ ${ }^{3}$ Hanoi University of Science and Technology, Vietnam
}

\begin{abstract}
Various characteristics such as age, sex, and polluted environment have been considered as the factors affecting trace element contamination of hair. However, those issues are still controversial. In order to clarify and confirm the effects of these factors, hair samples of residents living in and around Cho Dien lead/zinc mine were used in a preliminary assessment. The collected samples included 109 hair specimens in which 42 males and 67 females were identified and analyzed considering 4 metals $(\mathrm{Ca}, \mathrm{Cd}, \mathrm{Pb}, \mathrm{Zn})$. The results observed for males and females showed that a concentration of $\mathrm{Ca}$ was the highest level compared to those of other metals, followed by that of $\mathrm{Zn}$. The average levels of $\mathrm{Cd}$ and $\mathrm{Pb}$ of the male group were observed to be significantly higher than those of the female group whereas these values of $\mathrm{Ca}$ and $\mathrm{Zn}$ were lower. Statistical analysis showed a strong positive correlation between $\mathrm{Cd}$ and $\mathrm{Pb}$ for the whole population $(\mathrm{r}=0.679)$ as well as for the male hair $(\mathrm{r}=0.696)$ and the female hair $(\mathrm{r}=0.590)$. Higher concentrations of $\mathrm{Cd}$ and $\mathrm{Pb}$ were recorded in individuals living near the mine and more polluted areas in comparison with others, indicating increased systemic absorption of cadmium and lead. The most likely exposure pathways may be due to soil and water contamination, however, further investigations in this region should be performed.

Keywords: lead/zinc mine, human exposure, environmental factors, hair analysis, cadmium and lead relationship.
\end{abstract}




\section{Introduction}

In recent years, human hair has been considered a good screening tool for the evaluation of human health exposure to trace elements presented in the environment. Many previous studies have found the relationship of essential elements to diseases, metabolic disorders, environmental exposures, and nutritional status [1-5]. Determination of trace elements in human hair has received a great deal of attention in medical and environmental research due to its advantages such as easy collection, storage, and transportation to the laboratory for analysis.

Significant variations of metals in hair have been found among various subjects according to age, sex, hair colour and daily life conditions. Gordon [6] and Ziqiang Meng [7] observed the dependence of the elements on the age of the group. Other studies [8-10] determined trace elements in human hair and described the relationship with concentration, sex, and age of an individual, which provided a possible correlation with a number of factors related to genetical, nutritional and geographical characteristics. Dietary habits and environmental exposure may also be the reasons for variations in the hair trace metal values for male and female residents from specific geographical locations.

Moreover, hair has been widely used as a biological accumulation indicator of metals due to the fact that its efficiency enables us to indicate exposure or deficiencies over a period of time [11]. Numerous studies reported the relevance of the concentration of many elements $(\mathrm{Cd}, \mathrm{Pb}, \mathrm{Zn})$ to the environment or level of elements in other fluids, tissues or organs (liver, kidney, teeth, urine, and toenails) with hair mineral content [8, 12, 13]. Moon et al. [9] identified a relationship between the mean levels of metal in hair and environmental exposure and suggested that determination of trace element levels in hair may be a feasible method to detect the differences in environmental pollution.

In this study, hair samples were considered to be the first step for preliminary assessment in human exposure of a lead/zinc mine. Concentrations of toxic elements $(\mathrm{Cd}, \mathrm{Pb})$ and of essential metals $(\mathrm{Ca}, \mathrm{Zn})$ were analyzed in hair samples of residents living at different distances from the mine.

The objectives of this study are: (1) to determine metals $(\mathrm{Pb}, \mathrm{Cd}, \mathrm{Ca}, \mathrm{Zn})$ variation and accumulation in the residents living vicinity lead/zinc mine sites; (2) to examine how age, environmental factors, sex, and life style influenced metals exposure in inhabitants at different distances from the mine; (3) to investigate the relationships among elements of the collected samples according to age, sex; and (4) to confirm whether a hair specimen could be used as an index of environmental exposure to lead and cadmium.

\section{Materials and methods}

\subsection{Site description}

Cho Dien $\mathrm{Pb}-\mathrm{Zn}$ mine which is located in Northern Vietnam and surrounded by mountains reaching $220-1000 \mathrm{~m}$ above sea level, was estimated to be one of the 


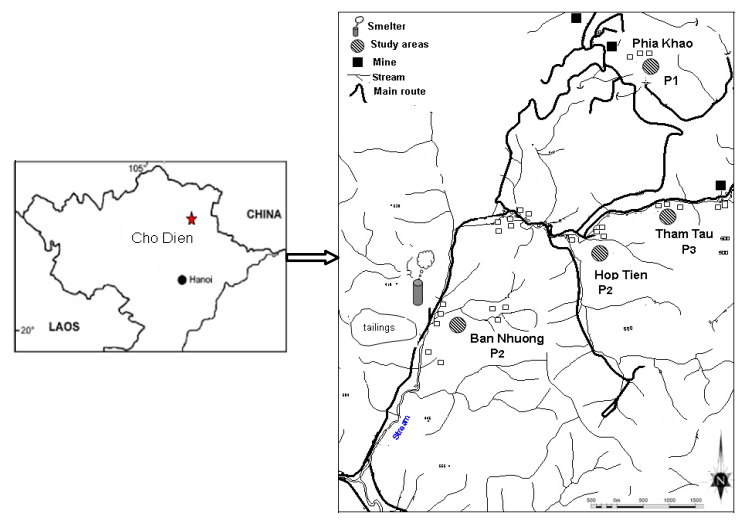

Figure 1: $\quad$ Map of study area.

largest lead/zinc mine in Vietnam. A tailing dam and a smelter processing plant are located along the stream (Fig. 1) which was affected by mining activities.

\subsection{Sample collection}

\subsubsection{Hair}

Human hair was collected from the inhabitants living near the lead-zinc mine in September, 2010. Residents were divided into three groups according to their residence: (1) living in mining areas (Phia Khao - P1) (2) near a smelter, located approximately $7 \mathrm{~km}$ downstream (Hop Tien and Ban Nhuong - P2) and hydrogeological and geochemical contaminated by metals (Tham Tau - P3). The total number of samples was 109 subjects consisting of 42 males and 67 females (2-72 year olds), without coloured or treated hair. Questionnaires provided information relating to the participants' characteristics such as: age, sex, residence, social behavior, education, health status, and the most consumed foodstuffs ingestion (home grown fruits and vegetables and the source of drinking water) also collected simultaneously. Six age classes were considered: (i) 2-6 years old; (ii) 7-11 years old; (iii) 12-19 years old and; (iv) 20-34 years old; (v) 35-60 years old; and (vi) over 60 years old. (Table 1).

Table 1: Characteristics of the studied inhabitants according to age and sex.

\begin{tabular}{|c|c|c|c|c|c|}
\hline \multirow{2}{*}{ Age group } & \multirow{2}{*}{$\begin{array}{l}\text { Age } \\
\text { range }\end{array}$} & \multirow{2}{*}{ Median age } & \multicolumn{3}{|c|}{ Number of inhabitants } \\
\hline & & & Male & Female & Total \\
\hline Children & $2-6$ & 4.2 & 12 & 11 & 23 \\
\hline Children of school age & $7-11$ & 8.6 & 11 & 11 & 22 \\
\hline Puberty & $12-19$ & 15.1 & 4 & 7 & 11 \\
\hline Youth & 20-34 & 28.5 & 4 & 9 & 13 \\
\hline Middle-age & $35-60$ & 42.8 & 11 & 25 & 36 \\
\hline Elderly & $>60$ & 69.3 & & 4 & 4 \\
\hline Total & & & 42 & 67 & 109 \\
\hline
\end{tabular}


Hair samples were cut by stainless steel scissors from the nape of the neck. The hair near the scalp (approximately $2-3 \mathrm{~cm}$ of recent growth) was used for analysis. Each sample was preserved in a sealed plastic bag, labelled with year of birth, sex, and residing place of individuals. All specimens were stored in a dry environment until delivered to the laboratory, where they were kept in desiccators before analysis.

\subsubsection{Environmental samples}

Drinking water samples were taken from 22 locations, including creeks, dug wells, and bore wells. Each water slot provides the drinking water for one or several households. All samples were collected in $500 \mathrm{ml}$ polyethylene containers previously washed with a $10 \% \mathrm{HNO}_{3}$ solution and rinsed with deionized water.

Surface soils $(0-15 \mathrm{~cm}$ in depth) were taken by trowel at different areas. All soil samples were stored in polyethylene bags.

\subsection{Sample preparation and analysis}

Approximately $0.5 \mathrm{~g}$ of all hair samples was cut into small pieces no longer than $1 \mathrm{~cm}$, thoroughly washed with a mixture of ethyl ether and acetone $(3: 1, \mathrm{v} / \mathrm{v})$ under continuous stirring for 10 mins. Then, samples were dried at $85^{\circ} \mathrm{C}$ for $1 \mathrm{~h}$, and treated with a dilute aqueous solution of EDTA $(5 \%)$ for $1 \mathrm{~h}$. The pieces were repeatedly rinsed with double-distilled water several times, and finally dried at $85^{\circ} \mathrm{C}$ for $12 \mathrm{~h}$ in an oven in order to determine the dry weight for the next steps. $0.25 \mathrm{~g}$ of each of the dried hair was digested in a microwave oven Milestone (USA) with the high-purity concentrated of $5 \mathrm{ml}(68 \%) \mathrm{HNO}_{3}$ and $1 \mathrm{ml} \mathrm{H}_{2} \mathrm{O}_{2}(30 \%)$.

Soil samples were dried at room temperature (approximately $30^{\circ} \mathrm{C}$ ) and ground to pass a $0.15-\mathrm{mm}$ mesh. Then, $0.25 \mathrm{~g}$ of sample was digested using aqua regia $\left(\mathrm{HCl} / \mathrm{HNO}_{3}=3: 1\right)$ (USEPA, 2001 a) by a microwave digestion method.

Hair and soil samples after digesting by microwave were filtered through Whatman GF/C filter papers in $50 \mathrm{ml}$ borosilicate volumetric flasks and made up to the mark with Milli-Q water. Blank samples were made for each batch digestion, without hair or soil samples, were prepared the same way with the real samples.

Water samples were filtered through a $0.45 \mu \mathrm{m}$ membrane filter, then acidified with $\mathrm{HNO}_{3}(0.2 \% \mathrm{v} / \mathrm{v})$. These samples were stored in a refrigerator at $4^{\circ} \mathrm{C}$ until physical-chemical analyses. Constituents $(\mathrm{Ca}, \mathrm{Cd}, \mathrm{Pb}$ and $\mathrm{Zn})$ in all solutions were determined by inductively coupled plasma-mass spectrometry (ICP/MS ELAN 900-Perkin Elmer) (detection limit of $\mathrm{Cd}, \mathrm{Pb}$ is $0.0001 \mathrm{mg} / \mathrm{L}$, and $\mathrm{Zn}$ is $0.001 \mathrm{mg} / \mathrm{L}$ ). Milli-Q water was used for the preparation of calibration standards and blank. Dilutions were made using $\mathrm{HNO}_{3}$ at $2 \%$. Three replicate determinations were performed for each sample. Sample blanks were also analyzed and subtracted every tenth sample. Analytical precision, estimated from triplicate analyses was in the range $5-10 \%$ for all analyzed elements. 


\section{Results and discussion}

\subsection{Distribution of metal levels in hair according to age}

Average metal content in the hair of 109 participants according to the age group are shown in Table 2. The most abundant element found in all the hair samples was $\mathrm{Ca}$, with concentrations reaching a peak at $5493 \mu \mathrm{g} / \mathrm{g}$, followed by others in order of abundance $\mathrm{Zn}>\mathrm{Pb}>\mathrm{Cd}$. The dependence of age on $\mathrm{Ca}, \mathrm{Cd}, \mathrm{Zn}$ and $\mathrm{Pb}$ contents is given in Fig. 2.

Table 2: Average concentration of metals in residents' hair according to age.

\begin{tabular}{|l|c|c|c|c|}
\hline Age group & $\mathrm{Cd}(\mu \mathrm{g} / \mathrm{g})$ & $\mathrm{Ca}(\mu \mathrm{g} / \mathrm{g})$ & $\mathrm{Pb}(\mu \mathrm{g} / \mathrm{g})$ & $\mathrm{Zn}(\mu \mathrm{g} / \mathrm{g})$ \\
\hline Children (2-6) & 2.368 & 739 & 198.3 & 254.1 \\
Conc. range & $\mathrm{Nd} .-11.48$ & $67.5-2470$ & $17.0-633$ & $56.8-856.6$ \\
\hline Children of school age (7-11) & 0.391 & 667 & 88.3 & 203.6 \\
Conc. range & $\mathrm{Nd}-2.345$ & $113-2099$ & $17.9-687.7$ & $101.3-787.8$ \\
\hline Puberty (12-19) & 0.457 & 981 & 42.6 & 154.2 \\
Conc. range & $\mathrm{Nd} .-1.823$ & $34-4016$ & $7.74-121.9$ & $44.3-243.7$ \\
\hline Youth (20-34) & 0.454 & 1412 & 42.9 & 315.7 \\
Conc. range & $\mathrm{Nd}-1.357$ & $498-2335$ & $5.5-129.5$ & $104.3-585.9$ \\
\hline Middle-age (35-60) & 0.716 & 1519 & 43.8 & 239 \\
Conc. range & $\mathrm{Nd}-4.584$ & $45.2-5493$ & $6.9-165.6$ & $103.9-735.6$ \\
\hline Elderly (>60) & 0.382 & 1116 & 18.69 & 166.8 \\
Conc. range & $0.191-0.794$ & $406-1809$ & $8.8-45.5$ & $101.6-274.3$ \\
\hline Whole subjects (n=109) & 0.929 & 1100 & 84.22 & 223 \\
& $\mathrm{Nd} .-11.48$ & $34-5493$ & $5.5-687.7$ & $56.8-856.6$ \\
\hline
\end{tabular}

Nd.: Not detected.

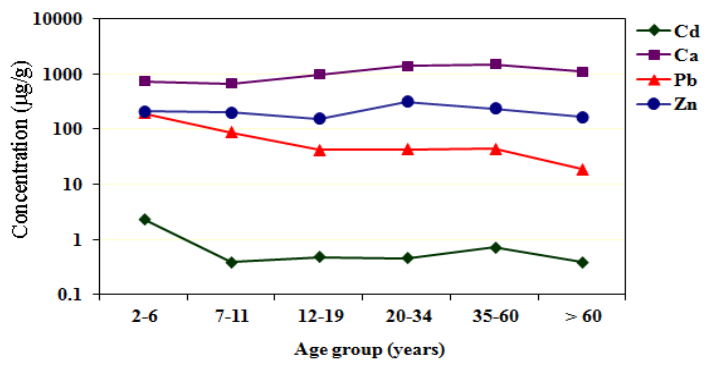

Figure 2: $\quad$ Dependence of $\mathrm{Ca}, \mathrm{Cd}, \mathrm{Pb}, \mathrm{Zn}$ on various age groups of residents.

The $\mathrm{Cd}$ and $\mathrm{Pb}$ levels in hair of the children age group (2-6 yrs) were the highest with the concentration reaching $11.48 \mu \mathrm{g} / \mathrm{g}$ and $633 \mu \mathrm{g} / \mathrm{g}$, respectively, followed by the group of children of school age (7-11 yrs). The Pb levels decreased sharply from this group (7-11 yrs) to the puberty group (12-19 yrs), whilst $\mathrm{Cd}$ values decreased considerably from children to children of school age group. Kopito et al. [14] investigated hair samples of 41 normal children in the group age under eight years, finding that hair contained 2-95 $\mu \mathrm{g} / \mathrm{g} \mathrm{Pb}$, with a mean of $24 \mu \mathrm{g} / \mathrm{g}$. When measuring the hair specimens of 16 children with 
chronic lead poisoning they found significantly higher lead levels $(42-975 \mu \mathrm{g} / \mathrm{g})$. In this study, the hair lead level on average was found to be $198 \mu \mathrm{g} / \mathrm{g}$ and $88.3 \mu \mathrm{g} / \mathrm{g}$ for $2-6 \mathrm{yrs}$ and $7-11 \mathrm{yrs}$ groups, which is considered to be toxic for children. The lowest concentration of $\mathrm{Cd}$ and $\mathrm{Pb}$ was found in the elderly group with the average concentration of 0.382 and $18.69 \mu \mathrm{g} / \mathrm{g}$, respectively. These results were in agreement with Wilhelm and Ohnesorge [15] who reported that individuals who were over 50 years old had less $\mathrm{Pb}$ in hair than those under 50 years old. There was no significant difference concerning the lead content in the hair among the age groups of puberty, youth and middle age.

It has been known that $\mathrm{Pb}$ and $\mathrm{Cd}$ can easily affect humans, especially children by ingestion or inhalation in high doses. Greater exposure to those elements of the children in the age group of 2-6 years could be explained as a higher probability of their ingesting with materials containing $\mathrm{Pb}$, e.g. atmospheric dust settling on toys, furniture, and play areas [16]. In fact, at the studied sites, the children in this group spend more time outside in comparison with others; and have regular contact with the surrounding environment which is highly contaminated by metals.

Wilhelm and Ohnesorge [15] also indentified that the influence of external exposure on scalp hair metal levels could be possibly due to more outdoor activities. Jin et al. [4], Tuthill [17] and WHO [18] reported that children under 6 years were particularly susceptible to lead poisoning because they absorbed a greater percentage of ingested lead than adults and their central nervous systems were still developing. Ziqiang Meng [7] suggested that the subject's age was the most important covariate in hair analysis studies. Authors also pointed out several metals of environmental contamination, including lead, cadmium which might affect younger children, approximately 5-12 years old, representing the most sensitive populations for hair analysis studies.

An average of $\mathrm{Ca}$ concentration went up gradually with age and reached the highest at $1519 \mu \mathrm{g} / \mathrm{g}$ in the middle age group, and then this parameter slightly decreased in the elderly group. No significant change in concentration of zinc in hair with age. Puberty group (12-19 yrs) had the lowest level of $\mathrm{Zn}$ and the highest was the youth group (20-34 yrs). Conversely, the findings were opposite with research [7], in which the authors showed the highest concentration of $\mathrm{Zn}$ in the 12-19 yr group and increased with age. Overall, the results showed that zinc content in the hair of young people was higher than that of older people, confirmed the findings of $[6,19]$.

\subsection{Correlation coefficient matrix among elements in hair samples}

The relationship between $\mathrm{Pb}$ and $\mathrm{Cd}$ has been found in strong correlation in the collected specimens at $\mathrm{r}=0.679(\mathrm{P}<0.01)$ while the inverse relationship was observed between $\mathrm{Cd}-\mathrm{Ca}$ at $\mathrm{r}=-0.190(\mathrm{P}<0.05)$ and $\mathrm{Pb}-\mathrm{Ca}$ at $\mathrm{r}=-0.234$ $(\mathrm{P}<0.01)$. Several studies have also found a close relationship between $\mathrm{Pb}$ and $\mathrm{Ca}[9,10]$. Mazlin et al. [11] explained that the close relationship between $\mathrm{Cd}$ and $\mathrm{Pb}$ levels in both hair types possibly indicated similar sources of exposure for both elements. Moon et al. [9] suggested that obviously the persistent 
correlations were due to similarities in the physicochemical properties of the metals. These characteristics may be found through: the geochemical composition of metal distribution in the crust, surface water; the amount of them in food sources, general metabolism, disposition and absorption in the human body. The correlation was less pronounced for $\mathrm{Zn}$ in the total population.

As observed that when lead concentration in hair increased, Ca concentration decreased. Some studies have shown that elevated blood $\mathrm{Pb}$ levels affected the concentration of $\mathrm{Ca}$ in the human body. In the present study, it was observed that not only in blood, but also lead in hair considerably influenced the Ca level. This study is in good agreement with Nowak and Chmielnicka [8] who found that $\mathrm{Pb}$ significantly influenced $\mathrm{Ca}$ levels. There is also the possibility of the dummy correlation from the correlation to age. Recently, the later mechanism of $\mathrm{Ca}$ and $\mathrm{Pb}$ occurring in the human body has not fully been explained.

An insignificant accumulating behaviour of $\mathrm{Cd}$ and $\mathrm{Zn}$ with the age of residents' hair was observed. A statistically significant negative correlation was found between hair lead level and age $(\mathrm{r}=-0.344)$ while $\mathrm{Ca}$ had a slight positive correlation $(\mathrm{r}=0.328)$. Elevated levels of $\mathrm{Ca}$ were found to accumulate in older age groups, which was probably due to metabolic retention of its relevance to aging process.

\subsection{Distribution of metal levels in hair according to gender}

Gender influenced the concentration of metals in hair. Average metal contents in relation to gender are shown in Table 3, while the average distribution of $\mathrm{Ca}, \mathrm{Cd}$, $\mathrm{Pb}, \mathrm{Zn}$ levels in hair of males and females in all subjects is given in Fig. 3.

The results in Table 3 showed that $\mathrm{Ca}$ concentration was found to be the highest, of which $\mathrm{Ca}$ values were 901 and $1225 \mu \mathrm{g} / \mathrm{g}$ for male and female, followed by $\mathrm{Zn}$ at 203.9 and $251.6 \mu \mathrm{g} / \mathrm{g}, \mathrm{Pb}$ at 121.8 and $60.2 \mu \mathrm{g} / \mathrm{g}$, respectively. The average Cd levels of male hair samples were found at $1.396 \mu \mathrm{g} / \mathrm{g}$ and for those of females at $0.637 \mu \mathrm{g} / \mathrm{g}$. The order of decrease in average concentration

Table 3: Average metal concentration of individuals' hair influenced by age and sex.

\begin{tabular}{|l|c|c|c|c|c|c|c|c|}
\hline \multirow{2}{*}{$\begin{array}{l}\text { Age } \\
\text { range }\end{array}$} & \multicolumn{2}{|c|}{$\mathrm{Cd}(\mu \mathrm{g} / \mathrm{g})$} & \multicolumn{2}{c|}{$\mathrm{Ca}(\mu \mathrm{g} / \mathrm{g})$} & \multicolumn{2}{c|}{$\mathrm{Pb}(\mu \mathrm{g} / \mathrm{g})$} & \multicolumn{2}{c|}{$\mathrm{Zn}(\mu \mathrm{g} / \mathrm{g})$} \\
\cline { 2 - 10 } & Male & Female & Male & Female & Male & Female & Male & Female \\
\hline $2-6$ & 3.254 & 1.403 & 816 & 653.4 & 232.7 & 160.8 & 173.1 & 251.4 \\
\hline $7-11$ & 0.558 & 0.223 & 529 & 806.3 & 125.5 & 51.12 & 191.8 & 215.3 \\
\hline $12-19$ & 0.344 & 0.283 & 649 & 1084 & 55.7 & 39.52 & 215.6 & 165.7 \\
\hline $20-34$ & 0.588 & 0.567 & 1141 & 801.3 & 42.9 & 79.27 & 336.3 & 244.5 \\
\hline $35-60$ & 0.721 & 0.714 & 1414 & 1565 & 46.9 & 42.38 & 215 & 249 \\
\hline$>60$ & & 0.514 & & 1117 & & 18.69 & & 166.8 \\
\hline Total & 1.396 & 0.637 & 901 & 1225 & 121.8 & 60.62 & 203.9 & 251.6 \\
\hline
\end{tabular}




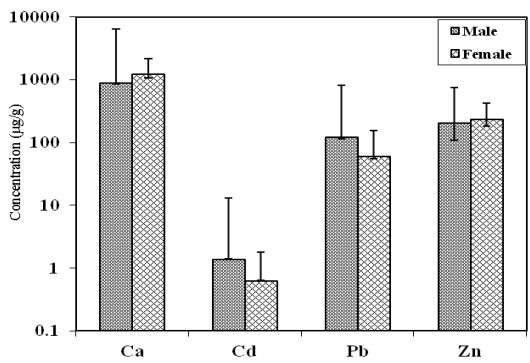

Figure 3: Average distribution of $\mathrm{Ca}, \mathrm{Cd}, \mathrm{Pb}, \mathrm{Zn}$ levels in hair of male and female.

for the metals followed the pattern: $\mathrm{Ca}>\mathrm{Zn}>\mathrm{Pb}>\mathrm{Cd}$ and this trend is similar for both genders. The $\mathrm{Pb}$ level of the male's hair was more than that of the female, suggesting that possibly males more outdoor activities made them intake more $\mathrm{Pb}$ from air containing $\mathrm{Pb}$ element.

Dependence of $\mathrm{Ca}, \mathrm{Cd}, \mathrm{Pb}, \mathrm{Zn}$ levels on various age groups of male and female participants is given in Figs. 4 and 5. As can be seen from these charts, the average $\mathrm{Pb}$ levels were observed to decrease considerably with age for both genders while $\mathrm{Cd}$ levels in those had the highest concentration at 2-6 yrs group then markedly declined to the youth group (20-34 yrs), and slightly went up again to the middle group. Zinc contents fluctuated slightly according to age groups for both sexes. The predominance of $\mathrm{Zn}$ in females (particularly in 26 yrs and 7-11 yrs group) may be due to the remarkable changes in bone mass and body composition occurring during puberty.

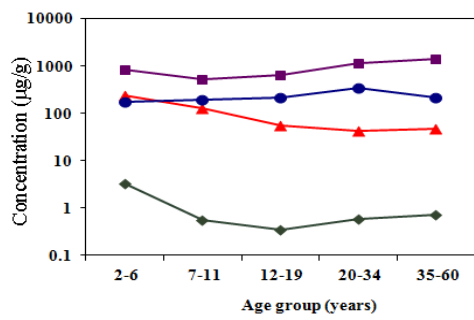

Figure 4: Dependence of $\mathrm{Ca}, \mathrm{Cd}$ $\mathrm{Pb}, \mathrm{Zn}$ levels on various age groups of males.

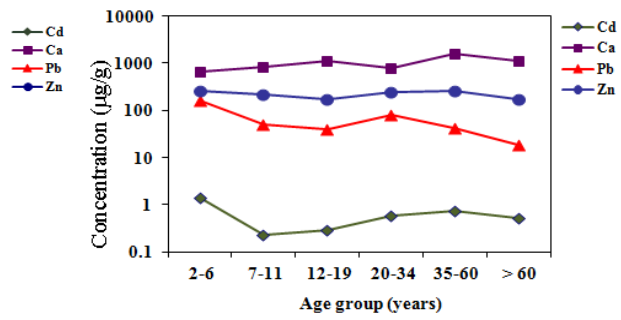

Figure 5: Dependence of $\mathrm{Ca}, \mathrm{Cd}, \mathrm{Pb}$, $\mathrm{Zn}$ levels on various age groups of females.

In comparing metal content between male and female, the average levels of $\mathrm{Cd}$ and $\mathrm{Pb}$ of the male hair $(\mathrm{Cd}, 1.396 \mu \mathrm{g} / \mathrm{g} ; \mathrm{Pb}, 121.8 \mu \mathrm{g} / \mathrm{g})$ were observed significantly higher than the female group $(\mathrm{Cd}, 0.637 \mu \mathrm{g} / \mathrm{g} ; \mathrm{Pb}, 60.2 \mu \mathrm{g} / \mathrm{g})$, except in the age group of 20-34 yrs and 2-6 yrs, $\mathrm{Pb}$ and $\mathrm{Cd}$ content of female hair was higher than those in male hair, respectively. However, essential metals ( $\mathrm{Ca}$ and $\mathrm{Zn}$ ) were present in higher concentration in female hair. 
Ziqiang Menn [7], when investigated hair $\mathrm{Pb}$ concentration of 1688 subjects also showed higher levels of $\mathrm{Pb}$ in male than in female. The conclusion in this study is also consistent with the findings of some previous studies $[6,8,9,15]$.

Possible effects of age and sex to lead accumulation in human hair was identified by Hammer et al. [20] who showed the lead levels arising from different degrees of environmental exposure. Significantly higher $\mathrm{Zn}$ concentrations in female hair as compared with male hair have been reported by $[6,7,21]$. Conversely, Caroli et al. [22] have reported that boys had higher mean $\mathrm{Zn}$ values than girls.

\subsection{Correlation coefficient among elements in male and female hair samples}

Statistical analysis showed the correlation coefficient matrix of metals in male hair $(n=42)$ and female hair $(n=67)$ among various metal pairs, in which a strong positive correlation between $\mathrm{Cd}-\mathrm{Pb}$ at $\mathrm{r}=0.696$ and $\mathrm{r}=0.590(\mathrm{P}<0.01)$ for the male hair and female hair, respectively. In the case of the male subjects, no significant correlation between the pairs except for the correlation between a pair of $\mathrm{Cd}-\mathrm{Pb}$. Others have also reported a high degree of association of cadmium and lead [7,9], thus their correlation in this study is suggested to be a general phenomenon. In addition, there was a slight correlation between the $\mathrm{Cd}-\mathrm{Zn}$ and $\mathrm{Pb}-\mathrm{Zn}$ at $\mathrm{r}=0.246$ and at $\mathrm{r}=0.261(P<0.05)$ was observed in female hair, respectively.

\subsection{Environmental exposure by cadmium and lead of inhabitants}

Average concentrations of $\mathrm{Pb}$ and $\mathrm{Cd}$ in soil and water samples are presented in Table 4. According to the table, the average lead content in drinking water samples did not significantly differ among the studied areas while cadmium concentration of all samples was lower than the allowable value, even some points have not been detected. Lead concentrations in drinking water from 22 samples on average were higher than the detection limit of $0.01 \mathrm{mg} / \mathrm{l}$ in three

Table 4: $\quad$ Average concentration of $\mathrm{Cd}, \mathrm{Pb}, \mathrm{Zn}$ in soil and drinking water.

\begin{tabular}{|c|c|c|c|}
\hline \multirow{4}{*}{ Water samples $(\mathrm{mg} / \mathrm{L})$} & Location $(\mathrm{n})$ & $\mathrm{Cd}$ & $\mathrm{Pb}$ \\
\hline & P1 (4) & 0.0014 (Nd.- 0.001$)$ & 0.017 (Nd.-0.022) \\
\hline & P2 (12) & 0.0005 (Nd. -0.002$)$ & 0.020 (Nd.-0.121) \\
\hline & P3 (4) & 0.0005 (Nd. -0.001$)$ & 0.016 (Nd.-0.034) \\
\hline 1329/2002/BYT/QĐ & & 0.003 & 0.01 \\
\hline \multirow[t]{3}{*}{ Soil sample (mg/kg) } & P1 (8) & $5.95(0.66-14.44)$ & $1043(166.0-1870)$ \\
\hline & P2 (10) & $3.45(0.227-11.51)$ & $781(113.5-1578)$ \\
\hline & P3 (4) & $4.01(0.866-9.79)$ & $689(315.5-928)$ \\
\hline $\begin{array}{l}\text { QCVN } \\
\text { 03:08/BTNMT }\end{array}$ & & 2 & 100 \\
\hline World's normal value & & 0.35 & 35 \\
\hline
\end{tabular}

1329/2002/BYT/QĐ: Hygiene Standard of Drinking Water-Ministry of Public Health, Vietnam. QCVN 03:08/BTNMT (Vietnam): National technical regulation on the allowable limits of heavy metals in the soils. 
areas. The maximum value was $0.02 \mathrm{mg} / \mathrm{l}$ at $\mathrm{P} 1$ that exceeded 2 times the WHO guideline value of $0.01 \mathrm{mg} / \mathrm{l}$ (WHO, 1996). The water supplies of the area may be considered to be potential sources of $\mathrm{Pb}$ for human of the studied sites. However, as there was no significant difference of the concentration of $\mathrm{Cd}$ in water samples among the polluted areas, it is difficult to assess the effect of water contaminated by $\mathrm{Cd}$ on people's exposure.

Soil samples were contaminated by $\mathrm{Pb}$ and $\mathrm{Cd}$. These values were significantly exceeded Vietnamese standard and also higher than the world's normal soil reported by Bowen 1979. The $\mathrm{Pb}$ levels decreased significantly from area $\mathrm{P} 1$ to $\mathrm{P} 3$. The average concentrations of $\mathrm{Pb}$ in soil (range is given in parentheses) of the areas P1, P2 and P3 were 1043 (166.0-1870); 781 (113.5$1578)$ and $689(315.5-928) \mathrm{mg} / \mathrm{kg}$, respectively.

Table 5 presents the differences between the $\mathrm{Pb}$ and $\mathrm{Cd}$ concentrations in inhabitants' hair at the three locations that reflect the individuals' exposure by environmental contamination. The levels of $\mathrm{Pb}$ and $\mathrm{Cd}$ in hair differed among the three locations. Hair $\mathrm{Pb}$ and $\mathrm{Cd}$ concentration on average in $\mathrm{P} 1$ were the highest in comparison with others at $133.7 \mu \mathrm{g} / \mathrm{g}$ and $1.7 \mu \mathrm{g} / \mathrm{g}$, respectively. There was no considerable difference of the hair cadmium levels between inhabitants living in P2 and P3 areas. The decreasing sequence of these substances in hair can be summarized as follows: $\mathrm{Pb}$ in hair: $\mathrm{P} 1>\mathrm{P} 2>\mathrm{P} 3$ and $\mathrm{Cd}$ in hair: $\mathrm{P} 1>\mathrm{P} 3>\mathrm{P} 2$.

Table 5: $\quad$ Area-related distribution of $\mathrm{Pb}-\mathrm{Cd}$ levels in subjects at the locations of residence.

\begin{tabular}{|l|c|c|}
\hline Location $($ Subject number) & $\mathrm{Cd}(\mu \mathrm{g} / \mathrm{g})$ & $\mathrm{Pb}(\mu \mathrm{g} / \mathrm{g})$ \\
\hline Most contaminated/ P1 $(\mathrm{n}=36)$ & $1.7(\mathrm{Nd} .-11.48)$ & $133.7(5.5-629.3)$ \\
\hline Near smelter plant/P2 $(\mathrm{n}=56)$ & $0.51(\mathrm{Nd} .-5.497)$ & $66.57(6.9-687.7)$ \\
\hline Near mine site/P3 $(\mathrm{n}=17)$ & $0.680(\mathrm{Nd} .-3.186)$ & $37.7(7.6-87.9)$ \\
\hline
\end{tabular}

In this study, $\mathrm{Pb}$ concentrations in hair of people in $\mathrm{P} 1$ is the highest, these levels were 2 times and 3.6 times higher than those at P2 and P3, respectively. This may be due to the fact that at P1 because of mines exploitation, though some parts were ceased, the cavities were still abandoned without remediation methods. The soil at the site has not been recovered. This will increase the release of lead containing dust and affect the children from spending their time on the most contaminated land.

Significant differences between levels of $\mathrm{Cd}$ and $\mathrm{Pb}$ in soil and in the hair of people in the three regions are shown in Table 5. It is seen that, the contamination of these elements in soil has been accumulated in people's hair in different areas (Figs. 6 and 7). The result is consistent with Boris [23] who found the highest lead concentrations of children's hair resided near a copper smelter where contaminated by high lead level. They revealed the influence of $\mathrm{Pb}$ concentration in soil to $\mathrm{Pb}$ hair level and pointed out that hair lead concentration in children strongly correlated with lead content soil at $r=0.74$. Pb concentration in hair specimens of the three regions was considerably different although those in water were almost equal. Hence, the presence of this element in water samples has not reflected obviously its impact on lead accumulation of these areas. 


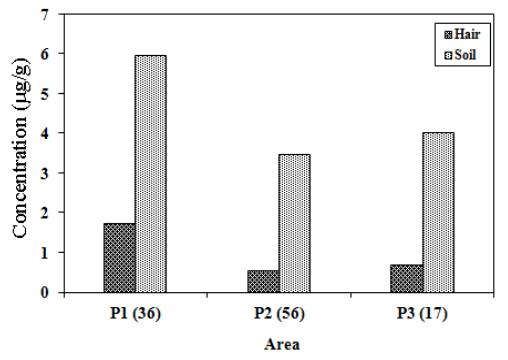

Figure 6: Cadmium content in residents' hair and soil relating to areas.

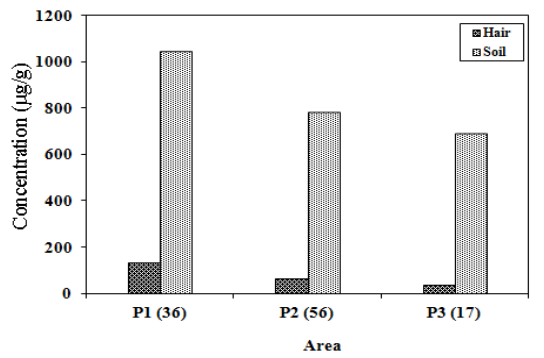

Figure 7:

Lead content in residents' hair and soil relating to areas.

\section{Conclusions}

In conclusion, the results of this study showed the dependence of different factors such as age, sex and environmental contamination to human exposure on metals accumulation. Age and sex of subjects were obviously influenced the concentrations of $\mathrm{Pb}, \mathrm{Ca}, \mathrm{Cd}$ in hair. According to age, $\mathrm{Cd}$ and $\mathrm{Pb}$ concentrations are the highest in the age group 2-6 and the lowest at the elderly group ( $>60 \mathrm{yrs}$ ) in all the participants. Lead level decreased considerably by the age. The predominance of $\mathrm{Ca}$ and $\mathrm{Zn}$ in hair was observed at the youth and middle groups. The value of zinc in this study was consistent with previous studies of normal human hair samples. Essential metals ( $\mathrm{Ca}$ and $\mathrm{Zn}$ ) were present in higher concentration in female in comparison with male in the whole population, while toxic metals $(\mathrm{Cd}$ and $\mathrm{Pb})$ were reversed.

Relationships which have been established in the study were confirmed in the literature for the whole population correlations. Only some correlations were confirmed by the study. The close relationship between the $\mathrm{Cd}$ and $\mathrm{Pb}$ hair levels for the whole population as well as both genders was found. High $\mathrm{Pb}$ concentrations in hair which have a significant influence to the content of $\mathrm{Ca}$ are shown in a slight negative relationship with $\mathrm{Pb}$ at $\mathrm{r}=-0234$.

The present study shows the cadmium and lead burden for the examined subjects, as a consequence of their contamination in environment. The most likely exposure pathways has found to be soil and water ingestions, in which soil metal levels are probably more effective than water levels in affecting hair levels.

Our results realize that the residents living in and around the lead/zinc mine may be exposed by elements, namely $\mathrm{Cd}$ and $\mathrm{Pb}$. Although the results from the study have not specified a proportion of $\mathrm{Pb}$ and $\mathrm{Cd}$ in environmental samples with concentrations in the hair, it can be shown the significant influence of factors such as age, gender and environmental exposure on the accumulation of metals in hair. These results also confirm that hair is a suitable material for 
biological monitoring with respect to lead and cadmium disposition in human beings.

There should be more research focusing on health risk assessment of people residing at the studied sites in near future. For biological monitoring, not only influences by age, sex, and environmental factors on metal levels in hair are, but also other factors such as individual metabolic activity, occupational exposure, geological characteristics of region and dietary habit of the inhabitants. In addition, the need to investigate samples of other biological specimens such as blood, urine as well as air monitoring should be done in order to provide helpful data for risk reduction to decrease the exposure efficiently.

\section{References}

[1] Bencko, V., Use of human hair as a biomarker in the assessment of exposure to pollutants in occupational and environmental settings. Toxicology, 101, pp. 29-39, 1995.

[2] Contiero, E., Folin, M., Trace elements nutritional status. Use of hair as a diagnostic tool. Biol. Trace Metal Res, 40 (2), 151-160, 1994.

[3] Duarte, M.A., Leao, E., Penna, F.J., Influence of nutritional status, age and sex on infant hair zinc concentration. Braz. J. Med. Res, 22, pp. 561-568, 1989.

[4] Jin Y, Liao Y, Lu C, Li G, Yang J, Health effects in children aged 3-6 years induced by environmental lead exposure. Ecotoxicology and Environmental Safety, 63, pp. 313-317, 2006.

[5] Hintz, H.F.: 2001. Hair analysis as an indicator of nutritional status, Journal of Equine Veterinary Science, 21(4), 2001.

[6] G.F. Gordon., Sex and age related differences in trace element concentrations in hair. Sci. Total Environ, 42, pp. 133-147, 1985.

[7] Ziqiang Meng., Age and Sex Related Differences in Zinc and Lead Levels in Human Hair, Bio. Trace Element Research, 61 (1), pp. 79-87, 1998.

[8] Barbara Nowak, and Jadwiga Chmielnicka., Relationship of Lead and Cadmium to Essential Elements in Hair, Teeth, and nails of Environmentally Exposed people. Eco. and Env. S., 46, pp. 265-274, 2000.

[9] J. Moon, A.J. Davison 1, T.J. Smith and S. Fadl., Correlation clusters in the accumulation of metals in human scalp hair: effects of age, community of residence, and abundances of metals in air and water supplies, Sci. Total Environ, 72, pp. 87-112, 1988.

[10] M. Wilhelm, A. Pesch, U. Rostek, J. Begerow, Concentrations of lead in blood, hair and saliva of German children living in three different areas of traffic density, Sci. Total Environ, 297, pp. 109-118, 2002.

[11] Mazlin B. Mokhtar, Almah Bt. Awaluddin, Lead in Blood and Hair of Population near an Operational and a Proposed Area for Copper Mining, Malaysia, Bul. Environ. Cont. and Tox., 52(1), pp. 149-154, 1994.

[12] McKenzie, J.M., Content of zinc in serum, urine, hair, and toenails of New Zealand adults. Am. J. Clin. Nutr, 32, pp. 570-579, 1979. 
[13] M. Wilhelm, I. Lombeck, D. Hafner and F.K. Ohnesorge, Factors influencing cadmium and lead concentrations in hair of children, Environmental Hygiene, Springer-Verlag, Berlin, pp. 152-155, 1988.

[14] Louis Kopito, M.S., Randolph K. Byers, M. D, and Harry Shwachman, M.D, Lead in Hair of Children with Chronic Lead Poisoning, J. Med, 276, pp. 949-953, 1967.

[15] Michael Wilhelm and Friedrich K. Ohnesorge., Cadmium, copper, lead, and zinc concentrations in human scalp and public hair, Sci. Total Environ, 92, 199-206, 1990.

[16] Schell L.M., Effect of pollutants on human prenatal and postnatal growth: noise, lead, polychlorobiphenyl compounds, and toxic wastes. Am. J. Phys. An, 34, pp. 157-188, 1991.

[17] Tuthill RW. Hair lead levels related to children's classroom attention-deficit behavior. Arch Environ Health; 51(3), pp. 214-220, 1996.

[18] WHO. Inorganic Lead. Environmental Health Criteria 165. World Health Organization Geneva, pp. 25-31, 1995.

[19] SB Deeming, CW Weber., Hair analysis of trace minerals in human subjects as influenced by age, sex, and contraceptive drugs. Am J Clin Nutr, 31, pp. 1175-1180, 1978.

[20] D. I. Hammer, J. F. Finklea, R. H. Hendricks, C. M. Shy, and R. J. M. Horton, Hair trace metal levels and environmental exposure, Am. J. Epi, 93(2), pp. 84-92.

[21] A. Taylor, Usefulness of measurements of trace elements., Ann. Clin. Biochem, 23, pp. 364-378, 1986.

[22] Caroli, S., Alimonti, A., Coni, E., Petrucci, F., Senofonte, O., Violante, N., The assessment of reference values for elements in human biological tissues and fluids: a systematic review. Crit. Rev. Anal. Chem, 24 (5-6), pp. 363-398, 1994.

[23] Boris A., Lead in Hair and Urine of Children and Adults from Industrialized Areas. Environmental Health, 49(1), pp. 59-62, 1994. 